\title{
Left shoulder pain in patients with old myocardial infarction could be a neuropathic pain from spinal epidural haematoma
}

\author{
Kota Sakaguchi, ${ }^{1}$ Yasuharu Tokuda ${ }^{2}$
}

${ }^{1}$ General Internal Medicine, Nakagami Hospital, Okinawa, Japan

${ }^{2}$ General Internal Medicine, Muribushi Okinawa for Teaching Hospitals, Urasoe, Okinawa, Japan

\section{Correspondence to}

Professor Yasuharu Tokuda, yasuharu.tokuda@gmail.com

Accepted 10 August 2018

\section{DESCRIPTION}

A 66-year-old Japanese man with medical history of old myocardial infarction and on daily aspirin presented to the emergency department with sudden onset of severe left shoulder pain. He reported no prior trauma and denied cold sweat, vomiting, chest or back pains. At the time of initial evaluation, cardiac and neurological examinations were normal and there was no tenderness over the shoulder joints or the spine. A diagnosis of acute myocardial infraction or aorta dissection was first suspected. However, ECG, serum troponin $\mathrm{T}$ concentration and contrast-enhanced CT of the chest showed negative results.

The patient was admitted to the emergency department under the diagnosis of possible acute coronary syndrome. But, several hours later, he suddenly developed mild weakness of the left upper and lower extremities without facial muscle involvement. Urgent MRI revealed cervical spinal epidural haematoma (SEH) with spinal cord compression mainly to the left side (figure 1). The patient underwent decompression laminectomy. Aspirin was considered as a contributing factor to the development of haematoma and thus it was discontinued for a week. The patient was restarted with aspirin 1 week after the operation since

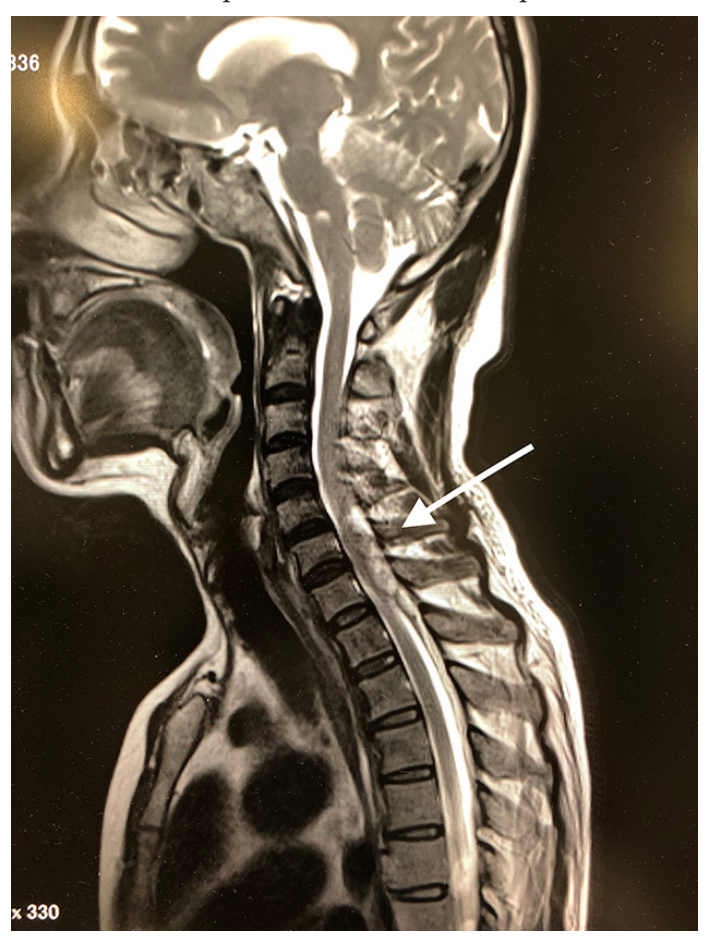

Figure 1 MRI showing epidural haematoma (white arrow) which compresses cervical spinal cord. we considered it was important to prevent myocardial infarction and the patient agreed with our plan. $\mathrm{He}$ was discharged home free from neurological symptoms after a course of rehabilitation.

In the current case, acute-onset left shoulder pain was initially suspected as a referred pain from acute coronary syndrome or acute aortic dissection, but later it was identified as neuropathic pain from $\mathrm{SEH}$. Spontaneous SEH is relatively rare, but, if not timely diagnosed and appropriately treated, it can lead to irreversible neurological deficits. Although left shoulder pain is commonly considered as a referred pain from acute coronary syndrome among patients, such as the current patient with old myocardial infarction, at high risk for cardiovascular events. Neuropathic pain from SEH should be considered as an important differential diagnosis with potentially serious neurological deficits, since it may develop spontaneously among patients on daily aspirin. ${ }^{12}$ MRI is a diagnostic test of choice for SEH. Urgent surgical decompression should be considered for patients with the development of neurological deficits.

\section{Patient's perspective}

I would like my case to be shared for doctors in the world for improving diagnosis of this serious condition which I experienced.

\section{Learning points}

Shoulder pain without tenderness could be a referred pain or a neuropathic pain.

- Left shoulder pain could be a symptom suggestive of spontaneous epidural haematoma of the cervical spine in patients on daily aspirin.

Contributors KS cared the patient and KS and YT wrote the manuscript.

Funding The authors have not declared a specific grant for this research from any funding agency in the public, commercial or not-for-profit sectors.

Competing interests None declared.

Patient consent Obtained.

Provenance and peer review Not commissioned; externally peer reviewed.

\section{REFERENCES}

1 Williams JM, Allegra JR. Spontaneous cervical epidural hematoma. Ann Emerg Med 1994;23:1368-70.

2 Locke GE, Giorgio AJ, Biggers SL, et al. Acute spinal epidural hematoma secondary to aspirin-induced prolonged bleeding. Surg Neurol 1976;5:293-6. 
Copyright 2018 BMJ Publishing Group. All rights reserved. For permission to reuse any of this content visit http://group.bmj.com/group/rights-licensing/permissions.

BMJ Case Report Fellows may re-use this article for personal use and teaching without any further permission.

Become a Fellow of BMJ Case Reports today and you can:

- Submit as many cases as you like

- Enjoy fast sympathetic peer review and rapid publication of accepted articles

Access all the published articles

- Re-use any of the published material for personal use and teaching without further permission

For information on Institutional Fellowships contact consortiasales@bmjgroup.com

Visit casereports.bmj.com for more articles like this and to become a Fellow 